Research Article

\title{
Presplitting Blasting the Roof Strata to Control Large Deformation in the Deep Mine Roadway
}

\author{
Chaowen Hu $\mathbb{D}^{1,2}$ Xiaojie Yang, ${ }^{3}$ Ruifeng Huang, ${ }^{3}$ and Xingen Ma $\mathbb{D}^{3,4}$ \\ ${ }^{1}$ Transportation Institute, Inner Mongolia University, Hohhot 010070, Inner Mongolia, China \\ ${ }^{2}$ China Coal Research Institute, Beijing 100013, China \\ ${ }^{3}$ State Key Laboratory for Geomechanics and Deep Underground Engineering, China University of Mining and Technology, \\ Beijing 100083, China \\ ${ }^{4}$ Huaneng Coal Technology Research Co., Ltd., Beijing 100010, China
}

Correspondence should be addressed to Chaowen Hu; chaowen_hu@163.com and Xingen Ma; 294185559@qq.com

Received 3 September 2020; Revised 1 October 2020; Accepted 12 October 2020; Published 30 October 2020

Academic Editor: Bingxiang Yuan

Copyright (C) 2020 Chaowen Hu et al. This is an open access article distributed under the Creative Commons Attribution License, which permits unrestricted use, distribution, and reproduction in any medium, provided the original work is properly cited.

As the mining depth increases, under the influence of high ground stress, the surrounding rock of deep mine roadways shows soft rock characteristics. Under the influence of mining disturbance at the working face, large deformation of the roadway has occurred. To control the large deformation of the roadway, many mines have adopted the form of combined support, which has continuously increased the support strength and achieved a certain effect. However, since the stress environment of the surrounding rock of the roadway has not been changed, large deformation of the roadway still occurs in many cases. Based on the theoretical basis of academician Manchao He's "short cantilever beam by roof cutting," this paper puts forward the plan of "presplitting blasting + combined support" to control the large deformation of the deep mine roadways. Without changing the original support conditions of the roadway, presplitting blasting the roof strata of the roadway, by cutting off the mechanical connection of the roof strata between the roadway and gob, improves the stress distribution of the roadway to control the large deformation. Through field tests, the results show that after presplitting blasting the roadway roof, the roadway roof subsidence is reduced by $47.9 \%$, the ribs displacement is reduced by $45.7 \%$, and the floor heave volume is reduced by $50.8 \%$. The effect is significant.

\section{Introduction}

China's coal resources buried below $1000 \mathrm{~m}$ are 2.95 trillion tons, accounting for $53 \%$ of the total coal resources $[1,2]$. At present, there are more than 100 coal mines in China with a depth of more than $600 \mathrm{~m}, 38$ coal mines with a depth of more than $1000 \mathrm{~m}$, and the deepest is more than $1500 \mathrm{~m}$ $[3,4]$. The existing research results show that with the increase in mining depth, the vertical stress continues to increase. The tectonic stress increases accordingly, forming a high stress condition of "high vertical stress and high tectonic stress" at a large buried depth, which easily leads to a series of problems such as large deformation, roof fall, rib spalling, and floor heave [5-7]. It brings hidden dangers to coal mine safety production.
As shallow coal resources are exhausted, the development of coal resources to deep is an objective and inevitable trend, and it is also a common problem faced by many mining countries in the world $[8,9]$. Some mines in Germany and Russia have mining depths exceeding $1400 \mathrm{~m}$, Canada has 30 mines exceeding $1000 \mathrm{~m}$, and the United States has 11 mines exceeding $1000 \mathrm{~m}[10,11]$. China's coal mining depth is increasing year by year at a rate of $10-20 \mathrm{~m}$ per year $[12,13]$. How to effectively control the large deformation of deep mine roadways has become a problem of the coal industry [14-16].

At present, domestic and foreign scholars have put forward many support theories for the deep mine roadway, such as the new Austrian tunneling method, the loose circle theory, the combined support theory, and the bolt shotcrete 
arc plate support theory. [17-19]. These theories believe that due to the buried depth, the deep mine roadway has shown the characteristics of the soft rock roadway [20-22]. A single rigid or flexible support method cannot effectively control the large deformation of the deep mine roadway. Therefore, it is necessary to adopt a variety of support methods to control the large deformation of the deep mine roadway $[23,24]$. These theories have played an important role in guiding the support of deep mine roadways. However, with the increase in mining depth, it has become more and more difficult to maintain the stability of the surrounding rock of deep mine roadways solely by supporting methods. To ensure the safety of deep mine roadways, many coal mines can only continuously increase the support strength and sometimes need to use passive methods such as roof ripping, rib expansion, and undercutting to ensure the section size of the roadway, which seriously restricts the transformation of coal mine enterprises to high production and efficiency [25-27].

Based on the theory of "short cantilever beam by roof cutting" proposed by academician Manchao He, this paper proposes a "presplitting blasting + combined support" scheme to control the large deformation of the deep mine roadway [28-30]. This paper takes the Xingcun Coal Mine of Shandong Tianan Mining Co., Ltd. as the engineering background to conduct research.

\section{Engineering Background}

Xingcun Coal Mine is located in Qufu City, Shandong Province. The west area of the minefield is the hanging wall of the Ziyang fault, the south is bounded by the Ziyang fault, the north and west are bounded by the minefield boundary, and the east is bounded by the F50 fault. The minefield area is about $36.86 \mathrm{~km}^{2}$. The ground elevation of 3307 working face is $52-55 \mathrm{~m}$, the underground elevation is -1110 to -1135 , and the average buried depth is $1165 \mathrm{~m}$. The roadway is affected by the pressure and geological conditions, and large deformation of the roadway appears. The most serious are the two shoulder sockets of the roadway. The top row of bolts at the top of the bank is covered by the top sinking, and there are phenomena such as steel strip tearing, bolt breakage, and anchor cable breakage. The floor heave of the roadway is large. This article takes the Xingcun Coal Mine 3307 ventilation roadway as the engineering background for research.

The main coal seam of 3307 working face is \#3 coal. According to drilling data, the average coal thickness of \#3 coal is $5.42 \mathrm{~m}$, the coal seam inclination is $11^{\circ}$, the coal seam structure is simple, and the coal seam's proctor hardness $f=2$. The comprehensive histogram of rock formations is shown in Figure 1.

The section shape of the 3307 ventilation roadway is a straight wall arc arch type. The net width of the roadway is $4100 \mathrm{~mm}$, the wall height is $2800 \mathrm{~mm}$, and the middle height of the roadway is $3500 \mathrm{~mm}$. The original support method is combined support of bolt, mesh, cable, and steel belt. KMG500-22-2400 type metal threaded anchor rod, SK18/ 8.0-1700Q type anchor cable, and metal diamond mesh made of $\# 8$ iron wire were used. The specification is $2500 \times 1350 \mathrm{~mm}$, and the grid size is $70 \times 70 \mathrm{~mm}$. The anchor rod is used in conjunction with the $\mathrm{W}$-shaped steel belt and was fastened on the steel belt with a special tray. The length of the steel belt is $4300 \mathrm{~mm}$, the row distance of the steel belt is $800 \mathrm{~mm}$, and the row distance between the bolts is $800 \times 800 \mathrm{~mm}$. The original support form of the roadway is shown in Figure 2.

\section{Scheme Design}

Without changing the original support scheme, this paper proposes a plan for presplitting blasting the roof strata of the roadway to control the large deformation of the deep mine roadway. First, the directional presplitting blasting method cuts off the force transmission path between the roof strata of the roadway and the gob, forcing the stress to transfer to the depth of the coal, which has the effect of pressure relief. Moreover, under the action of presplitting blasting, the impact of roof strata collapse on the surrounding rock of the roadway can be reduced. Then, cooperate with the original support method to achieve the purpose of controlling the large deformation of the roadway. The key technical parameters of presplitting blasting mainly include the depth, angle, and spacing of presplitting blasting holes.

Arrange presplitting blasting holes at the side of the gob on the roof of the 3307 ventilation roadway. According to the drilling data on site, there is a layer of fine sandstone of about $10 \mathrm{~m}$ above the roadway. In the mining process of the working face, the deformation and fracture process of this layer of fine sandstone have a great influence on the mine pressure appearance of the roadway. Therefore, the depth of the presplitting blasting hole should ensure that this layer of fine sandstone is cut so that it can collapse in a short time after the working face is mined. The depth of presplitting blasting hole is initially designed to be $17 \mathrm{~m}$.

Presplitting blasting the roof strata of the roadway before the working face is mined, and the roof strata on the gob side and the roadway side is cut off at the presplitting blasting hole after the working face has been mined. The deflection angle of the presplitting blasting hole to the gob side is too small, which is not conducive to the stability of the roof strata of the roadway and will bring difficulties to the roadway support, while the angle is too large, and it is not conducive to the collapse of the gob roof strata. After presplitting blasting the roof strata of the roadway, the mechanical model of the roof strata can be simplified as Figure 3.

When the hinged structure is formed, the conditions for the rock mass to remain stable are as follows:

$[T \cos \theta+(R-F) \sin \theta] \cdot \tan \varphi=(R-F) \cos \theta-T \sin \theta$.

Equation (1) can be simplified as follows:

$$
T \sin (\theta+\varphi)=(R-F) \cos (\theta+\varphi) .
$$

So, $\alpha=\arctan ((R-F) / T)-\varphi$ 


\begin{tabular}{|c|c|c|c|c|c|c|c|c|}
\hline $\begin{array}{l}\text { Thickness } \\
\text { (m) }\end{array}$ & Column & Lithology & $\begin{array}{c}\text { Bulk } \\
(\mathrm{GPa})\end{array}$ & $\begin{array}{l}\text { Shear } \\
\text { (GPa) }\end{array}$ & $\begin{array}{c}\text { Tension } \\
(\mathrm{MPa})\end{array}$ & $\begin{array}{c}\text { Cohesion } \\
(\mathrm{MPa})\end{array}$ & $\begin{array}{l}\text { Friction angle } \\
\qquad(i \tilde{a})\end{array}$ & $\begin{array}{l}\text { Density } \\
\left(\mathrm{kg} / \mathrm{m}^{3}\right)\end{array}$ \\
\hline 6.75 & & Mudstone & 0.97 & 1.45 & 1.92 & 1.88 & 33 & 2100 \\
\hline 0.46 & & $\# 1$ coal & 0.81 & 1.22 & 1.69 & 1.71 & 31 & 1400 \\
\hline 0.55 & & Mudstone & 0.97 & 1.45 & 1.92 & 1.88 & 33 & 2100 \\
\hline 3.23 & & Fine sandstone & 1.21 & 2.58 & 2.92 & 3.35 & 36 & 2300 \\
\hline 3.52 & & Mudstone & 0.97 & 1.45 & 1.92 & 1.88 & 33 & 2100 \\
\hline 4.75 & & Fine sandstone & 1.21 & 2.58 & 2.92 & 3.35 & 36 & 2300 \\
\hline 5.76 & & Siltstone & 2.81 & 3.22 & 4.53 & 3.82 & 41 & 2460 \\
\hline 10.08 & & Fine sandstone & 1.21 & 2.58 & 2.92 & 3.35 & 36 & 2300 \\
\hline 0.45 & & $\# 2$ coal & 0.81 & 1.22 & 1.69 & 1.71 & 31 & 1400 \\
\hline 4.53 & & Siltstone & 2.81 & 3.22 & 4.53 & 3.82 & 41 & 2460 \\
\hline 0.39 & & Mudstone & 0.97 & 1.45 & 1.92 & 1.88 & 33 & 2100 \\
\hline 5.42 & & $\# 3$ coal & 0.81 & 1.22 & 1.69 & 1.71 & 31 & 1400 \\
\hline 1.43 & & Mudstone & 0.97 & 1.45 & 1.92 & 1.88 & 33 & 2100 \\
\hline 2.44 & & Siltstone & 2.81 & 3.22 & 4.53 & 3.82 & 41 & 2460 \\
\hline 11.13 & & Fine sandstone & 1.21 & 2.58 & 2.92 & 3.35 & 36 & 2300 \\
\hline 2.56 & & Mudstone & 0.97 & 1.45 & 1.92 & 1.88 & 33 & 2100 \\
\hline 3.53 & & Siltstone & 2.81 & 3.22 & 4.53 & 3.82 & 41 & 2460 \\
\hline 2.44 & & Fine sandstone & 1.21 & 2.58 & 2.92 & 3.35 & 36 & 2300 \\
\hline 1.66 & & Mudstone & 0.97 & 1.45 & 1.92 & 1.88 & 33 & 2100 \\
\hline
\end{tabular}

FIgURE 1: Coal seam stratum synthesis histogram.

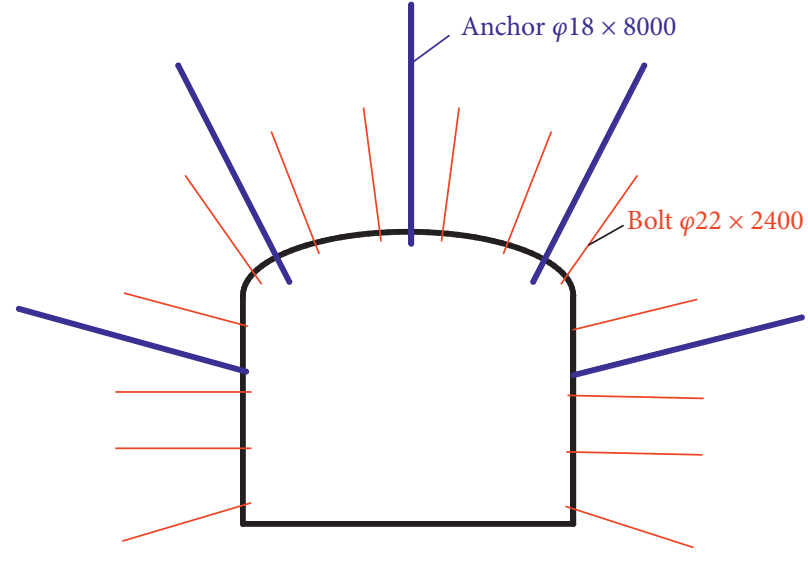

(a)

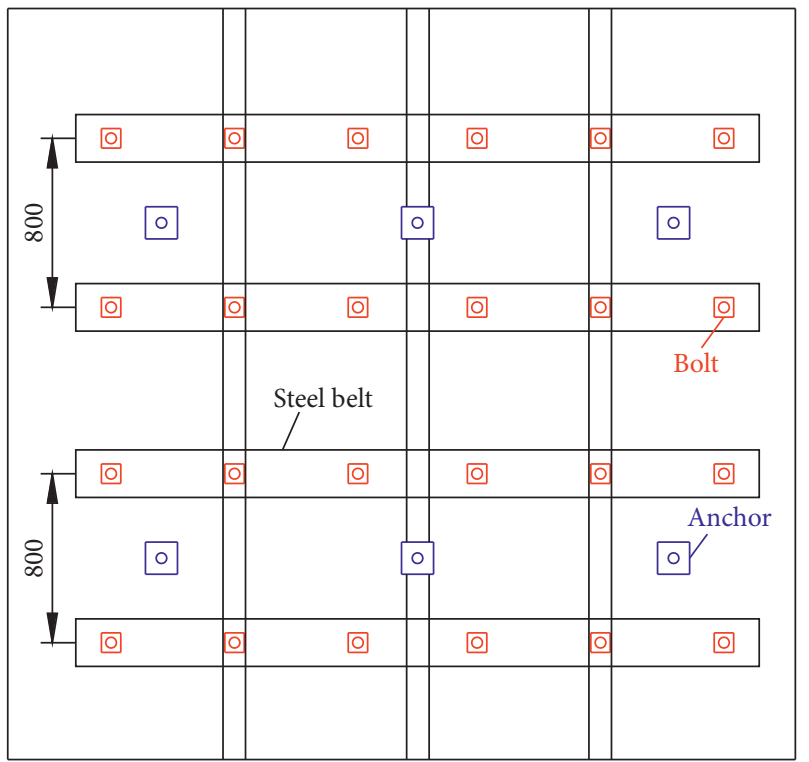

(b)

FIGURE 2: Original support form of the 3307 ventilation roadway. (a) Front view of original support form of the roadway. (b) Top view of original support form of the roadway. 

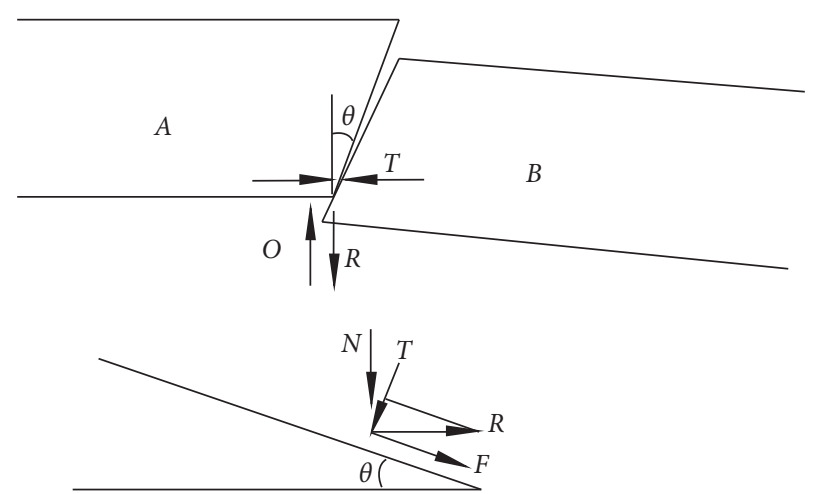

FIgURE 3: The mechanical model of the roof strata.

$$
\left\{\begin{array}{l}
f=\tau \times h \times 1, \\
R=\rho g h d,
\end{array}\right.
$$

where $T$ is the horizontal force of the rock block in $\mathrm{kN} ; R$ is the load of block B in $\mathrm{kN} ; F$ is the working resistance of a single prop in $\mathrm{kN}$; $h$ is the height of roof cutting in $\mathrm{m} ; \varphi$ is the friction angle of the rock block in ${ }^{\circ} ; \alpha$ is the angle of the presplitting blasting hole in ${ }^{\circ} ; f$ is the shear force of the rock block in $\mathrm{kN}$; $\rho$ is the density of the rock strata in $\mathrm{kg} / \mathrm{m}^{3}$; and $d$ is the width of the roadway in $\mathrm{m}$.

For convenient calculation, a component of $T$ can be approximated as $f$, where " $f=T \sin \alpha$ ". According to the actual conditions of the 3307 ventilation roadway, the field parameters were chosen as follows: $\varphi=27^{\circ}, t=0.13 \mathrm{MPa}$, $\rho=2500 \mathrm{~kg} / \mathrm{m}^{3}, h=16 \mathrm{~m}$, and $d=4.1 \mathrm{~m}$.

According to the aforementioned theoretical calculation, when the angle of the presplitting blasting borehole is in the range of $10^{\circ}-15^{\circ}$, the roof strata of the roadway can remain stable. For comprehensive consideration of the convenience of construction and engineering experience of other mines, the angle between the presplitting blasting hole and the vertical is designed to be $15^{\circ}$.

Adopting bidirectional energy blasting technology, to pack the explosives in the tube, symmetrical openings on both sides of the energy collecting tube form a weak blasting surface [31-33]. As shown in Figure 4(a), after the explosive is detonated, the detonation wave will form a directional concentrated energy flow in the direction of the weak surface on both sides of the energy collecting tube, forming a cutting effect on the roof strata. As shown in Figure 4(b), the detonation wave generates concentrated tensile stress along the direction of the working face. The low tensile strength of the rock is used to force the presplitting blasting hole to penetrate along the energy-gathering direction to form a directional presplitting blasting section.

According to previous engineering experience, the bidirectional energy of concentrated blasting hole spacing is generally in the range of 400-600 $\mathrm{mm}$, and the blasting effect is better. Numerical simulation was carried out on the roof strata formation of \#3 coal in Xingcun Coal Mine, and LSDYNA software was used to numerically analyze the presplitting blasting hole spacing of $400 \mathrm{~mm}, 500 \mathrm{~mm}$, and
$600 \mathrm{~mm}$ to determine the best blast hole spacing. The simulation results are shown in Figure 5.

As shown in Figure 5, when the space between the presplitting blasting borehole was $400 \mathrm{~mm}$, the stress superposition was too strong and easily caused the borehole to collapse. When the space between the presplitting blasting borehole was $500 \mathrm{~mm}$, the stress superposition was strong enough to run through the roof strata. When the space between the presplitting blasting borehole was $600 \mathrm{~mm}$, the stress superposition was too feeble to run through the roof strata. Based on the numerical simulation, considering the previous engineering experience and engineering quantity, the space between the presplitting blasting borehole was selected to be $500 \mathrm{~mm}$.

The original support method of the roadway remains unchanged, and the combined support plan of "bolt + anchor + wire + steel + belt + shotcrete" is still selected. The support plan can be adjusted at the location where the local surrounding rock of the roadway is poor to increase the support strength.

\section{Numerical Simulation}

To understand the effect of pressure relief by presplitting blasting, Flac3D software was used to simulate the two working conditions of presplitting blasting and non-presplitting blasting the roof strata of the roadway. A numerical model was established according to the geological conditions of the \#3 coal seam in the Xingcun Coal Mine. The mechanical parameters of the roof and floor rock strata are shown in Figure 1. The model length, width, and height were $600 \times 300 \times 70 \mathrm{~m}$; the vertical boundary force was applied to the upper boundary; the lower boundary was fixed in the vertical direction; and the front, rear, left, and right boundaries were fixed in the horizontal direction [34-36]. The width of the simulated working face was $200 \mathrm{~m}$, the thickness of the coal seam was $3.5 \mathrm{~m}$, and the width and height of the roadway were $4.0 \times 3.5 \mathrm{~m}$. The stress distribution for presplitting blasting the roof strata of the roadway is shown in Figure 6(a), and the stress distribution without presplitting blasting the roof strata of the roadway is shown in Figure 6(b). 


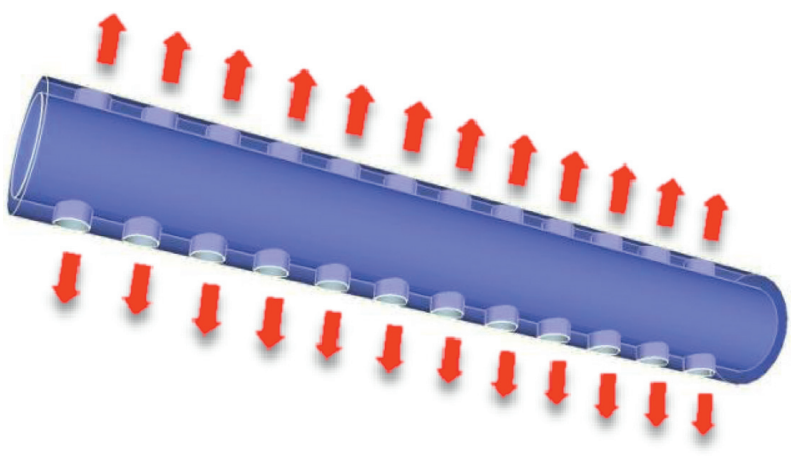

(a)

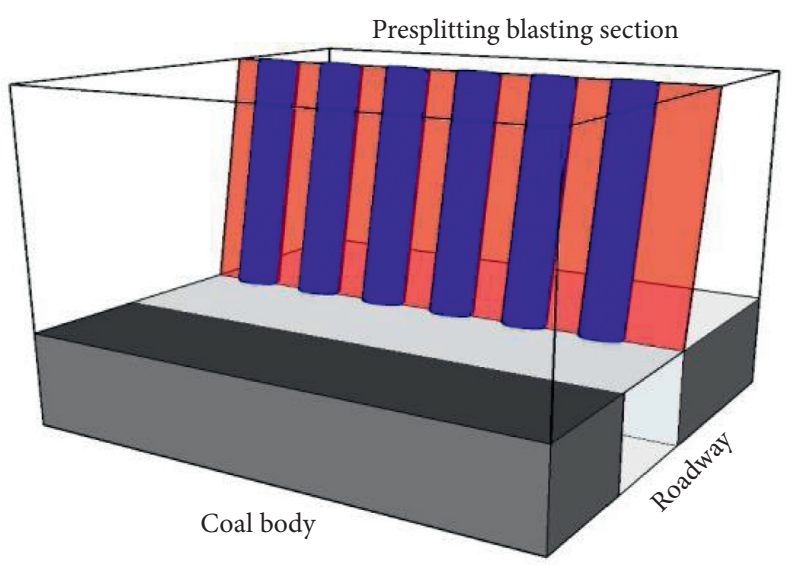

(b)

Figure 4: Bidirectional energy blasting technology. (a) Principle of bidirectional energy blasting. (b) Presplitting blasting the roof strata.

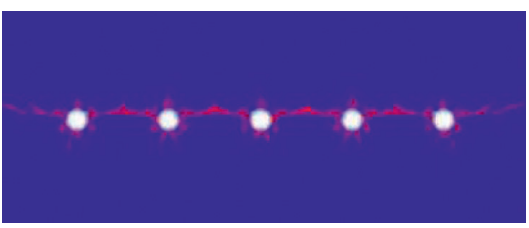

(a)

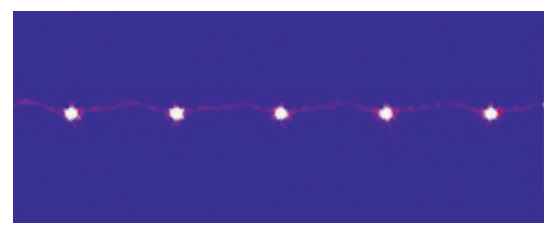

(b)

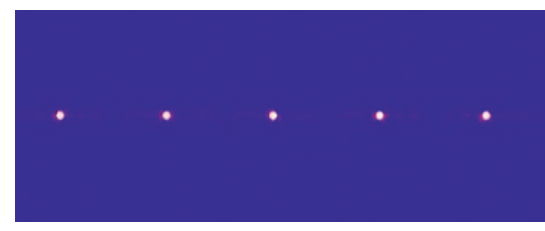

(c)

Figure 5: Blasting effect of different blast hole spacing. (a) Blasting spacing $400 \mathrm{~mm}$. (b) Blasting spacing $500 \mathrm{~mm}$. (c) Blasting spacing $600 \mathrm{~mm}$.

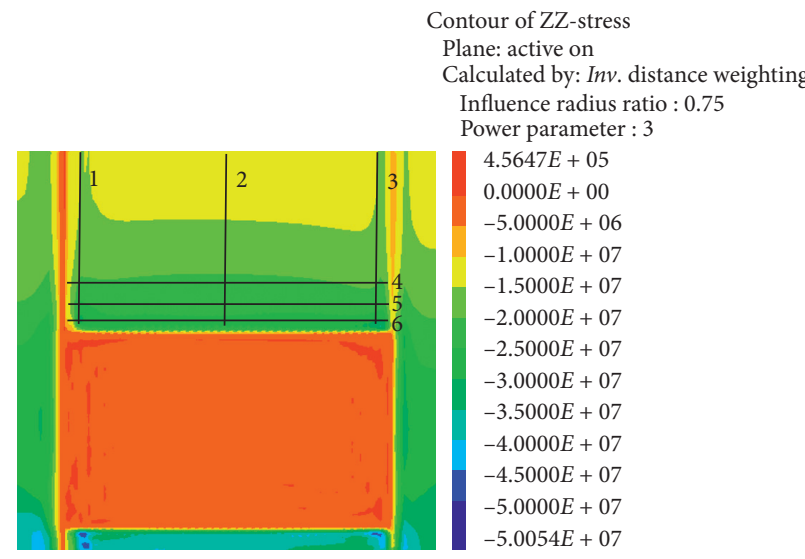

(a)

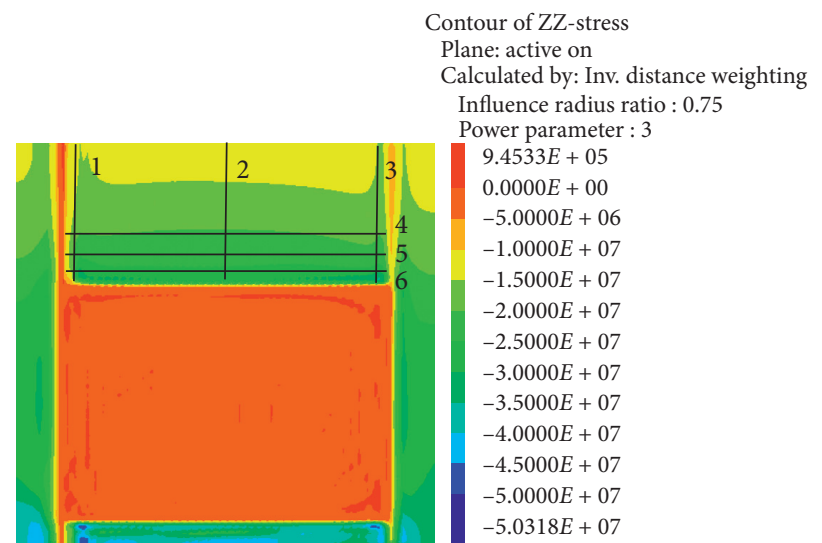

(b)

Figure 6: Stress distribution of two working conditions. (a) Presplitting blasting the roof strata. (b) Non-presplitting blasting the roof strata.

\subsection{Characteristics of Stress Distribution in front of Working} Face. To understand the influence of presplitting blasting on the stress distribution in front of the working face, stress measurement lines were arranged at the same position in front of the working face. As shown in Figure 6, \#1 \#3 survey lines were arranged perpendicular to the working face, and \#4-\#6 survey lines were arranged parallel to the working face. \#1 survey line was $5 \mathrm{~m}$ away from the mining side of the 3307 haulage roadway, \#2 survey line was located in the middle of the working face, \#3 survey line was $5 \mathrm{~m}$ away from the mining side of the 3307 ventilation roadway, \#4 survey line was $20 \mathrm{~m}$ in front of the working face, \#5 survey line was $10 \mathrm{~m}$ in front of the working face, and \#6 survey line was $5 \mathrm{~m}$ in front of the working face. The stress monitoring curves are shown in Figure 7. 

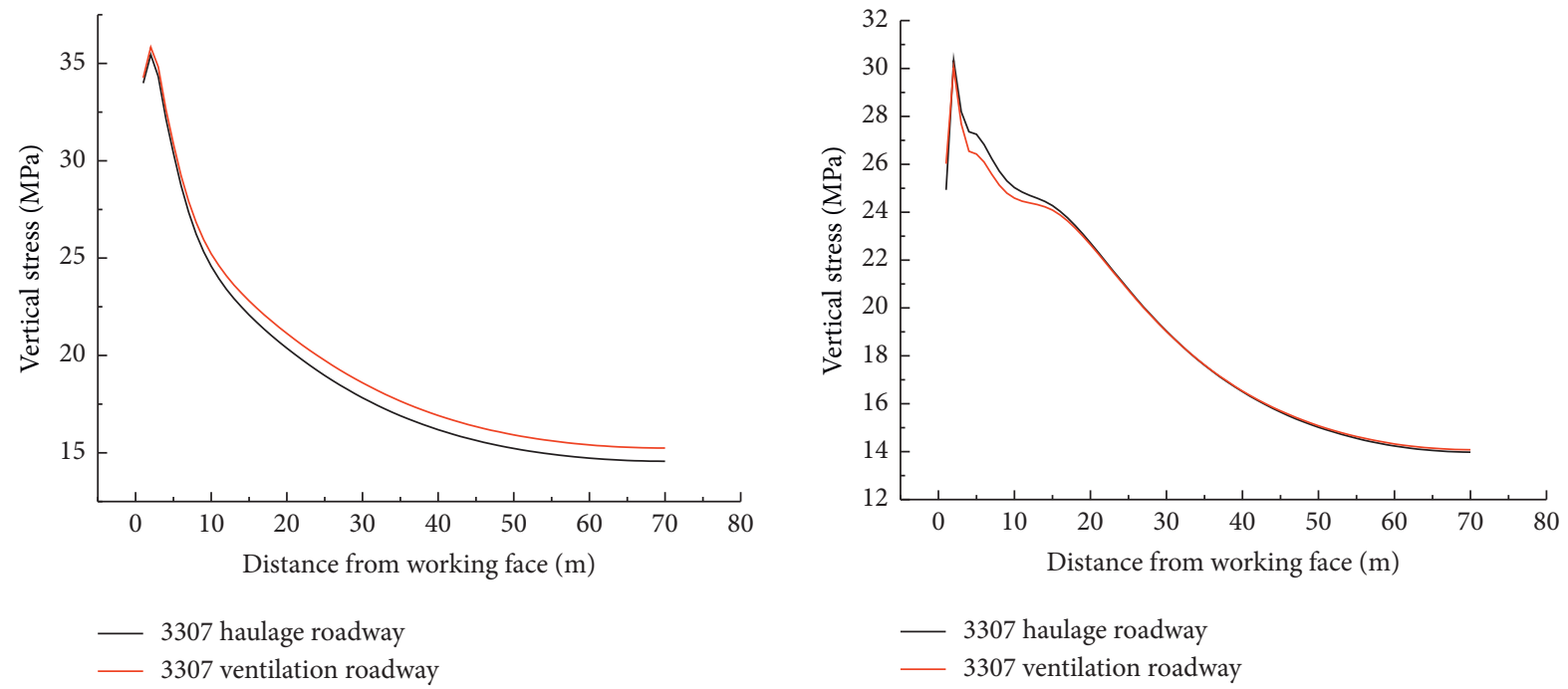

(a)

(b)

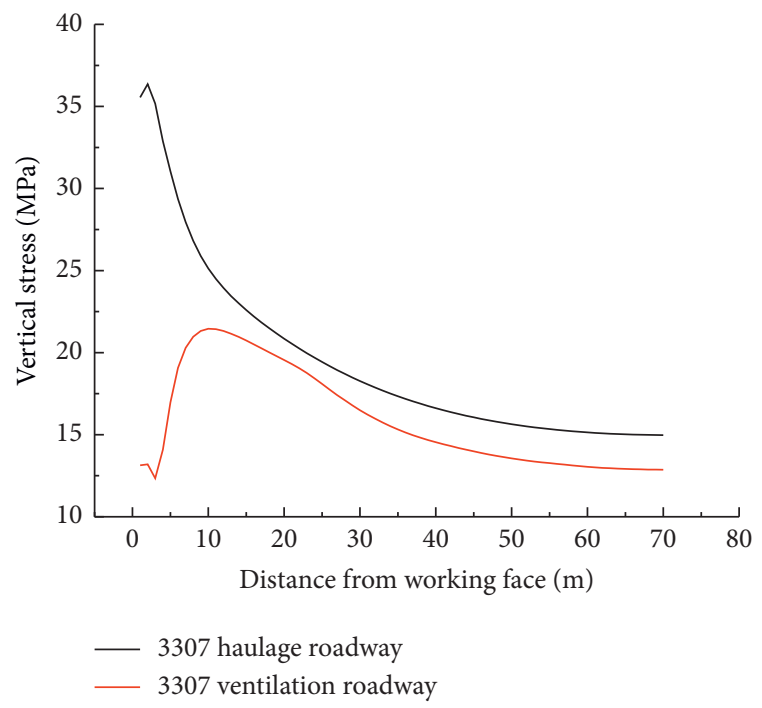

(c)

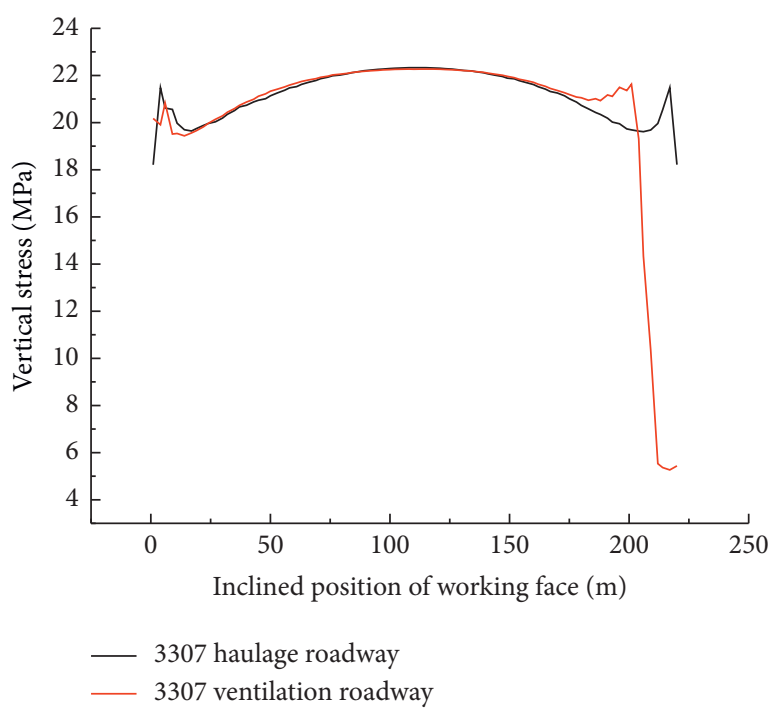

(d)

FIgUre 7: Continued. 


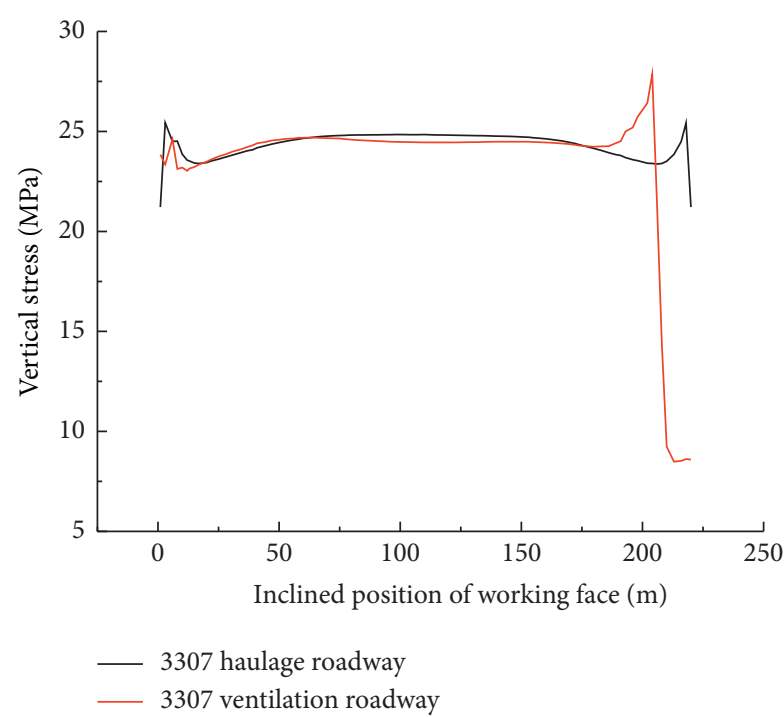

(e)

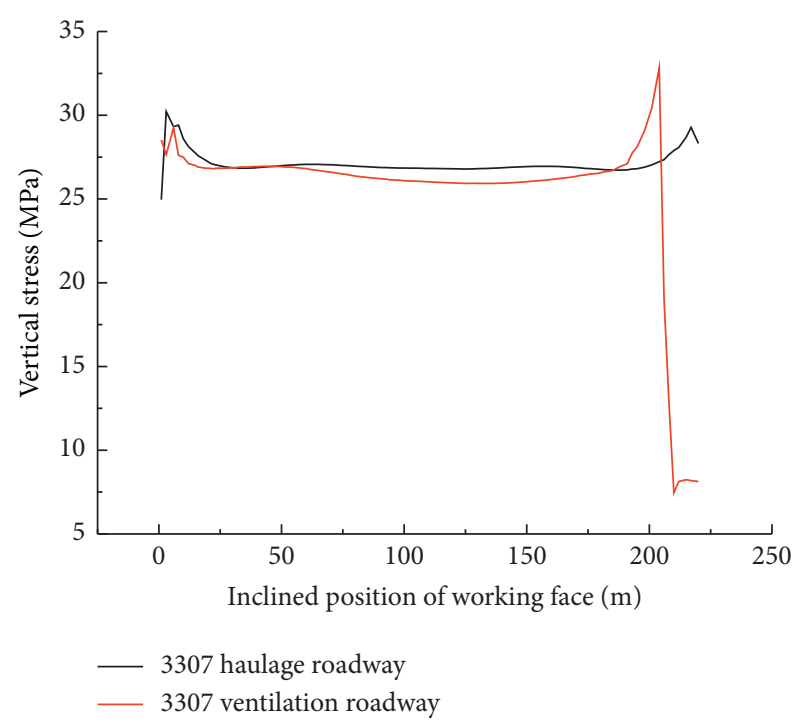

(f)

Figure 7: Vertical stress curves of two working conditions. (a) Stress monitoring value of \#1 survey line. (b) Stress monitoring value of \#2 survey line. (c) Stress monitoring value of \#3 survey line. (d) Stress monitoring value of \#4 survey line. (e) Stress monitoring value of \#5 survey line. (f) Stress monitoring value of \#6 survey line.

By comparing and analyzing whether the roadway roof strata was presplitting blasted, the vertical stress changes in the front of the working face under the two working conditions; it can be seen that the change of stress of the \#1 survey line and the \#2 survey line was same, and the vertical stress of the \#3 survey line under the presplitting blasting the roof strata is significantly smaller than the vertical stress without presplitting blasting. Comparing and analyzing the stress changes of \#4-\#6 survey lines, it can be seen that without presplitting blasting the roof strata of the roadway, the stress in front of the working face shows that the stress on both sides of the roadway is higher than that on the middle of the working face. The stress concentration area at both ends of the working face was close to the roadway. The presplitting blasting of the roof strata was carried out, and the stress concentration area on the side of the presplitting blasting of the working face is transferred to the depth of the coal seam, forming a stress reduction area of about $30 \mathrm{~m}$.

\subsection{Characteristics of Lateral Stress Distribution on Working} Face. To understand the influence of presplitting blasting on the lateral stress distribution of the working face, five measuring lines were arranged at the same position on the working face. As shown in Figure 6, \#7-\#11 survey lines were located behind the working face, and the distances were $5 \mathrm{~m}, 10 \mathrm{~m}, 20 \mathrm{~m}, 50 \mathrm{~m}$, and $100 \mathrm{~m}$, respectively. The stress distribution cloud diagrams of \#7-\#11 survey lines are shown in Figure 8.

As shown in Figure 8, in the presplitting blasting the roadway roof strata, the average stress concentration area was $12.8 \mathrm{~m}$ away from the roadside, which is an increase of $56.3 \%$ compared with the roadway roof strata without presplitting blasting, which effectively improves the stress distribution of the surrounding rock of the roadway, and the effect of pressure relief was good.

\section{Engineering Application}

To verify the pressure relief effect of presplitting blasting the roof strata of the roadway, a field test was carried out in the 3307 ventilation roadway. Before mining the working face, perform presplitting blasting on the roof strata of the 3307 ventilation roadway. The depth of the presplitting blasting hole is $17 \mathrm{~m}$, the angle with the vertical direction is $15^{\circ}$, the distance is $500 \mathrm{~mm}$, and the original support method remains unchanged. To further study the pressure relief effect of presplitting blasting the roof strata of the roadway, the ground pressure monitoring of the 3307 working face and the roadway was carried out.

5.1. Ground Pressure Monitoring of the 3307 Working Face. The working resistance of hydraulic support in 3307 working face was monitored on site. A total of 128 hydraulic supports were installed in 3307 working face. To facilitate the analysis of the impact of presplitting blasting on the appearance of ground pressure, the hydraulic supports were divided into three areas, of which the \#1-\#30 hydraulic supports in the end of the working face are the upper area, the \#31-\#97 hydraulic supports in the middle of the working face are the middle area, and the \#98-\#128 hydraulic supports in the tail of the working face subjected to presplitting blasting are the lower area. The working resistance monitoring curves of the hydraulic support are shown in Figure 9.

The maximum pressure and average pressure of the hydraulic support in each area of the 3307 working face were, respectively, counted, as shown in Table 1. 


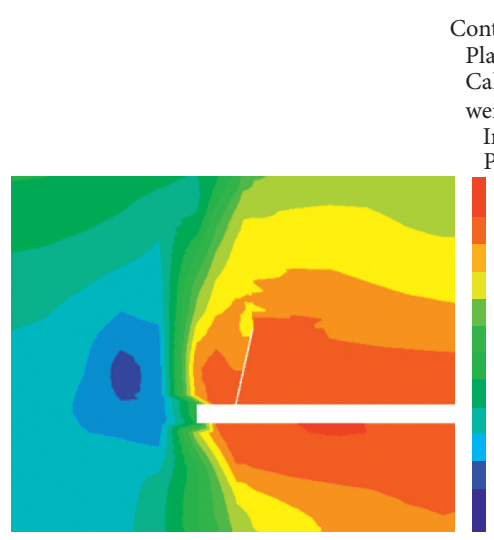

ontour of ZZ-stress

Plane: active on

Calculated by: Inv. distance weighting

luence radius ratio : 0.75

wer parameter : 3

$6.9326 E+04$

$0.0000 E+00$

$-2.5000 E+06$

$-5.0000 E+06$

$-7.5000 E+06$

$-1.0000 E+07$

$-1.2500 E+07$

$-1.5000 E+07$

$-1.7500 E+07$

$-2.0000 E+07$

$-2.2500 E+07$

$-25000 E+07$

.

$-3.0000 E+07$

$-3.0402 E+07$

(a)

Contour of ZZ-stress

Plane: active on

Calculated by: Inv. distance

weighting

Influence radius ratio : 0.75

Power parameter : 3

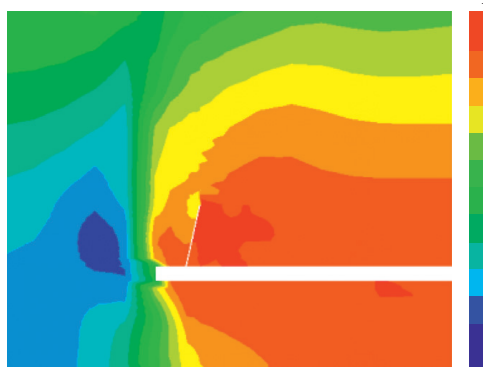

$1.2579 E+06$

$.0000 E+00$

$-2.5000 E+06$

$-5.0000 E+06$

$-7.5000 E+06$

$-1.0000 E+07$

$-1.2500 E+07$

$-1.5000 E+07$

$-1.7500 E+07$

$-2.0000 E+07$

$-2.2500 E+07$

$-2.5000 E+07$

$-2.7500 E+07$

$-3.0000 E+07$

$-3.0461 E+07$

(c)

Contour of ZZ-stress

Plane: active on

Calculated by: Inv. distance

weighting

Influence radius ratio : 0.75

Power parameter : 3

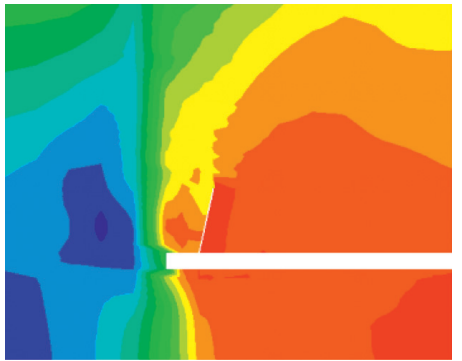

$1.5175 E+06$

$0.0000 E+00$

$-2.5000 E+06$

$-5.0000 E+06$

$-5.0000 E+06$
$-7.5000 E+06$

$-7.5000 E+06$

$-1.0000 \mathrm{E}+07$

$-1.2500 E+07$

$-1.5000 E+07$

$-1.7500 E+07$

$-2.0000 E+07$

$-2.2500 E+07$

$-2.5000 \mathrm{E}+07$

$-2.7500 E+07$

$-3.0000 E+07$

$-3.1213 E+07$

(e)

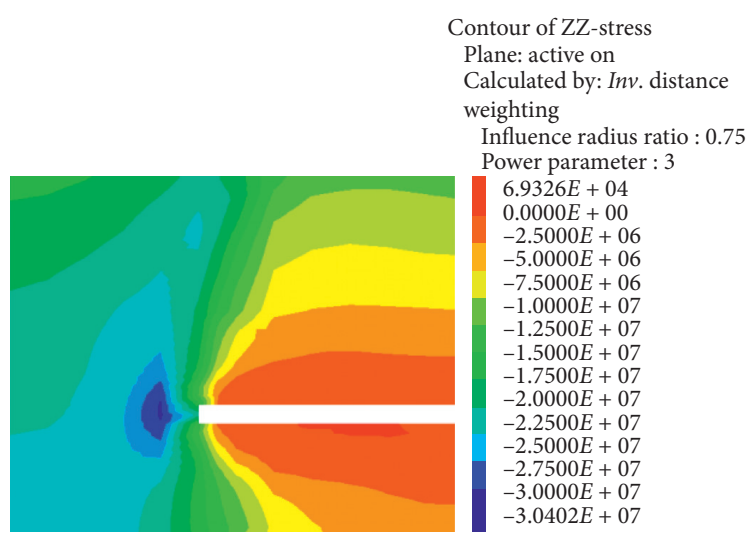

(b)

Contour of ZZ-stress

Plane: active on

Calculated by: Inv. distance

weighting

Influence radius ratio : 0.75

Power parameter : 3

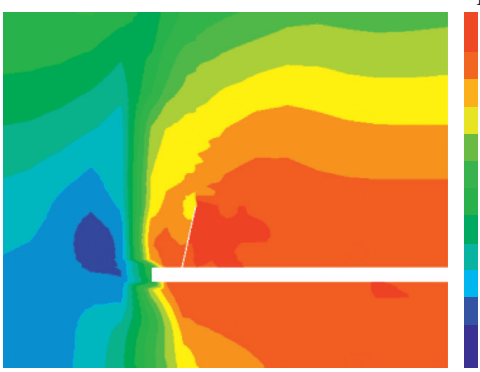

$1.2579 E+06$

$0.0000 E+00$

$-2.5000 E+06$

$-5.0000 E+06$

$-7.5000 E+06$
$-1.0000 E+07$

$-1.2500 E+07$

$-1.5000 E+07$

$-1.7500 E+07$

$-2.0000 E+07$

$-2.2500 E+07$

$-2.5000 E+07$

$2.7500 E+07$

$-2.7500 E+07$
$-3.0000 E+07$

$-3.0461 E+07$

(d)

Contour of ZZ-stress

Plane: active on

Calculated by: Inv. distance

weighting

Influence radius ratio : 0.75

Power parameter : 3

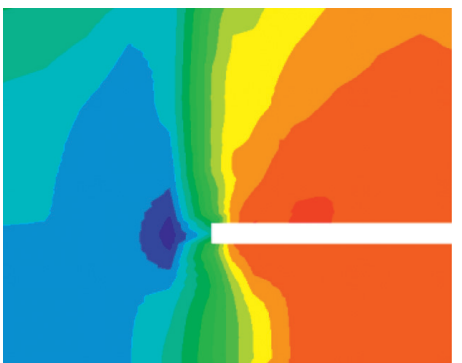

$1.5175 E+06$

$0.0000 E+00$

$-2.5000 E+06$

$-5.0000 E+06$

$-7.5000 E+06$

$-1.0000 E+07$

$-1.2500 E+07$

$-1.5000 E+07$

$-1.7500 E+07$

$-2.0000 E+07$

$-2.2500 E+07$

$-2.5000 E+07$

$2.7500 E+07$

$-3.0000 E+07$

$-3.1213 E+07$

(f)

FIgure 8: Continued. 


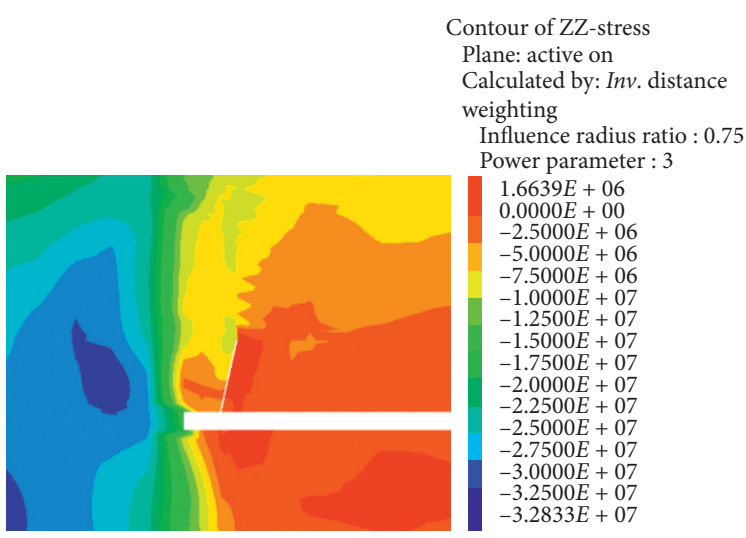

(g)

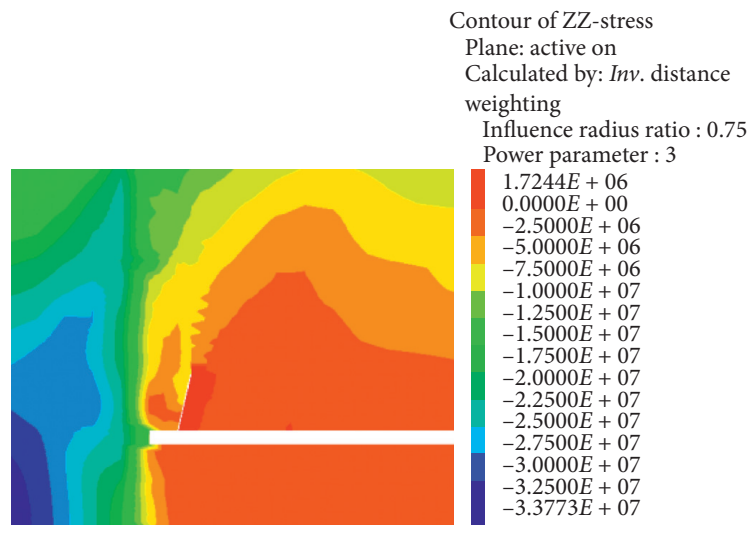

(i)

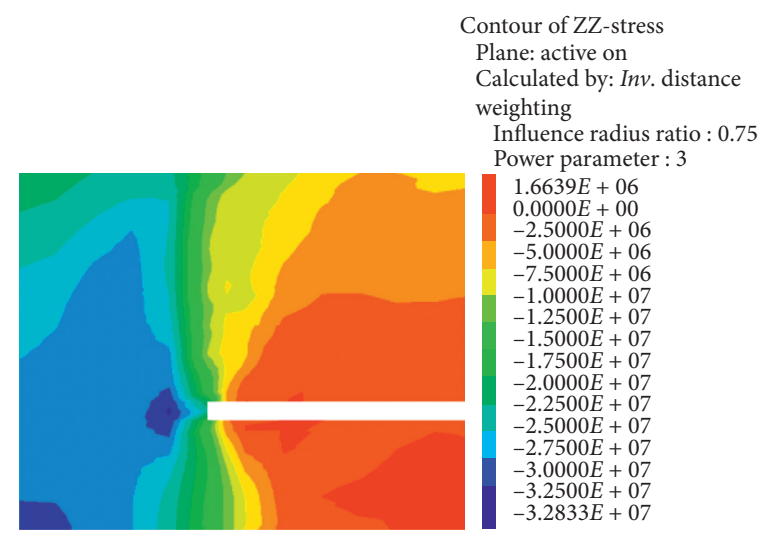

(h)

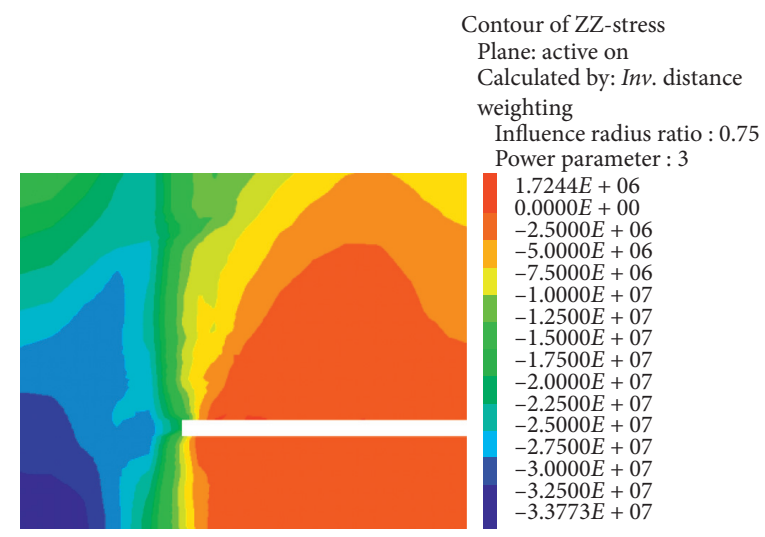

$(\mathrm{j})$

FIGURE 8: Lateral stress of working face of two working conditions. (a) \#7 survey line with presplitting blasting. (b) \#7 survey line without presplitting blasting. (c) \#8 survey line with presplitting blasting. (d) \#8 survey line without presplitting blasting. (e) \#9 survey line with presplitting blasting. (f) \#9 survey line without presplitting blasting. (g) \#10 survey line with presplitting blasting. (h) \#10 survey line without presplitting blasting. (i) \#11 survey line with presplitting blasting. (j) \#11 survey line without presplitting blasting.

The analysis shows that compared with the upper area and the middle area, the maximum pressure of the hydraulic support in the lower area affected by the presplitting blasting is reduced by $9.9 \mathrm{MPa}$ and $7.7 \mathrm{MPa}$, respectively, by $26.5 \%$ and $21.9 \%$, respectively; the average pressure was reduced by $14.9 \mathrm{MPa}$ and $13.6 \mathrm{MPa}$, respectively, by $48.9 \%$ and $46.6 \%$, respectively. The effect of pressure relief by presplitting blasting is good, which is consistent with the numerical simulation results.

5.2. Ground Pressure Monitoring of the Roadways. To understand the influence of presplitting blasting on the lead abutment pressure, the working resistance of single props in the 3307 ventilation roadway was monitored on site, and the 3307 haulage roadway which was not presplitting blasting was compared.

Install two single props in the 3307 ventilation roadway and haulage roadway at $50 \mathrm{~m}, 100 \mathrm{~m}$, and $150 \mathrm{~m}$ positions in front of the working face, and install pressure monitors, of which the $\# 1$ and $\# 2$ props lead the working face by $50 \mathrm{~m}$, the $\# 3$ and \#4 props lead the working face by $100 \mathrm{~m}$, and the \#5 and \#6 props lead the working face by $150 \mathrm{~m}$. The monitoring curves of the working resistance of the single props are shown in Figure 10.

As shown in Figure 10(a), the load of the single prop in 3307 haulage roadway increases significantly at $30 \mathrm{~m}$ ahead of the working face, and the load reached the maximum at $7 \mathrm{~m}$ ahead of the working face, and the maximum is $26.4 \mathrm{MPa}$. The load of the single prop in the 3307 ventilation roadway increases significantly at $20 \mathrm{~m}$ ahead of the working face, and the load reached the maximum at $5 \mathrm{~m}$ ahead of the working face, and the maximum is $22.7 \mathrm{MPa}$. Figures $10(\mathrm{~b})$ and $10(\mathrm{c})$ show similar forces on the single props. The load of the single prop in the 3307 haulage roadway starts to increase at $80 \mathrm{~m}$ ahead of the working face, and the load increases significantly at $30 \mathrm{~m}$ ahead of the working face. The load reached the maximum at $7 \mathrm{~m}$ ahead of the working face, and the maximum is $27.2 \mathrm{MPa}$. The load of the single prop in the 3307 ventilation roadway starts to increase at $50 \mathrm{~m}$ ahead of the working face, and the load increases significantly at $20 \mathrm{~m}$ ahead of the working face. The load reached the maximum at $5 \mathrm{~m}$ ahead of working face, and the maximum is $22.8 \mathrm{MPa}$. After presplitting blasting the roof strata of the roadway, the influence range of the lead 


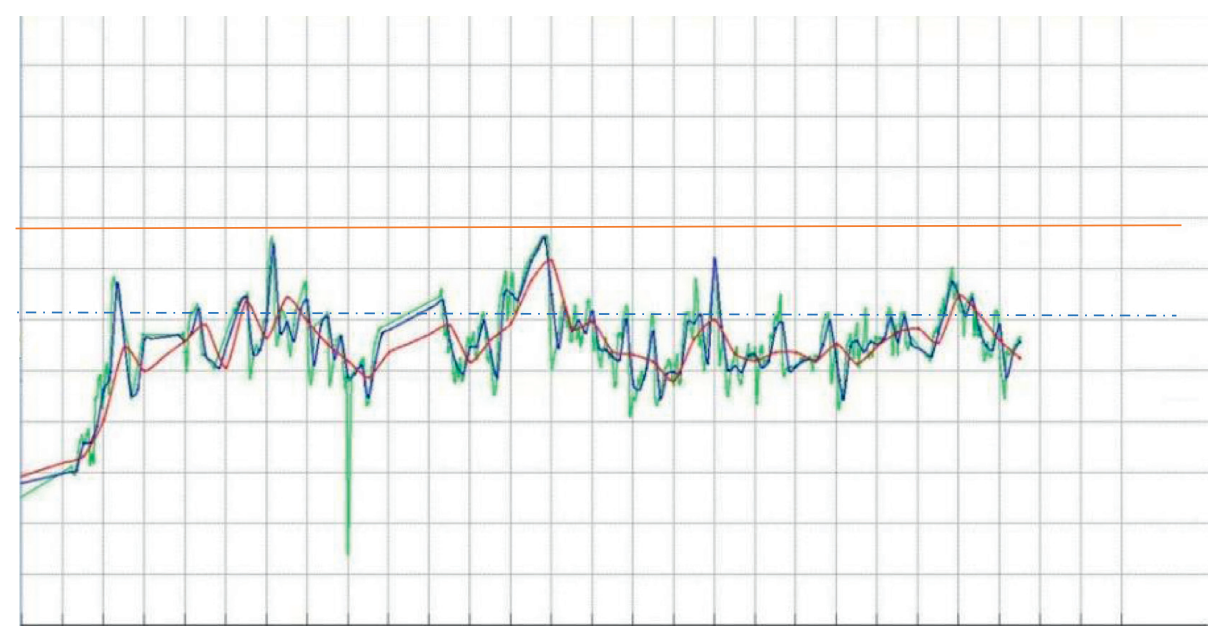

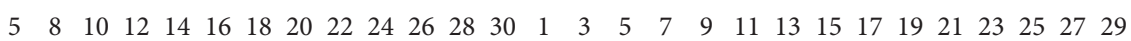

_ Maximum load 37.5 MPa

-..- Average load $30.5 \mathrm{MPa}$

(a)

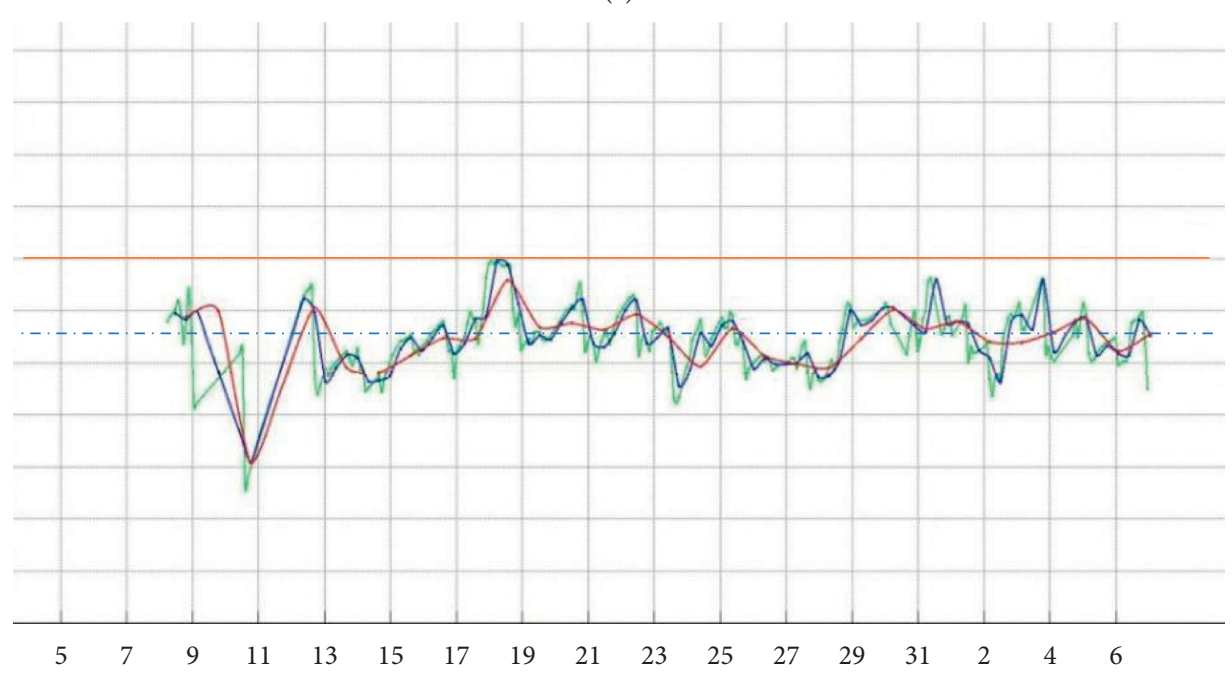

— Maximum load 35.2 MPa

...- Average load 29.2 MPa

(b)

Figure 9: Continued. 


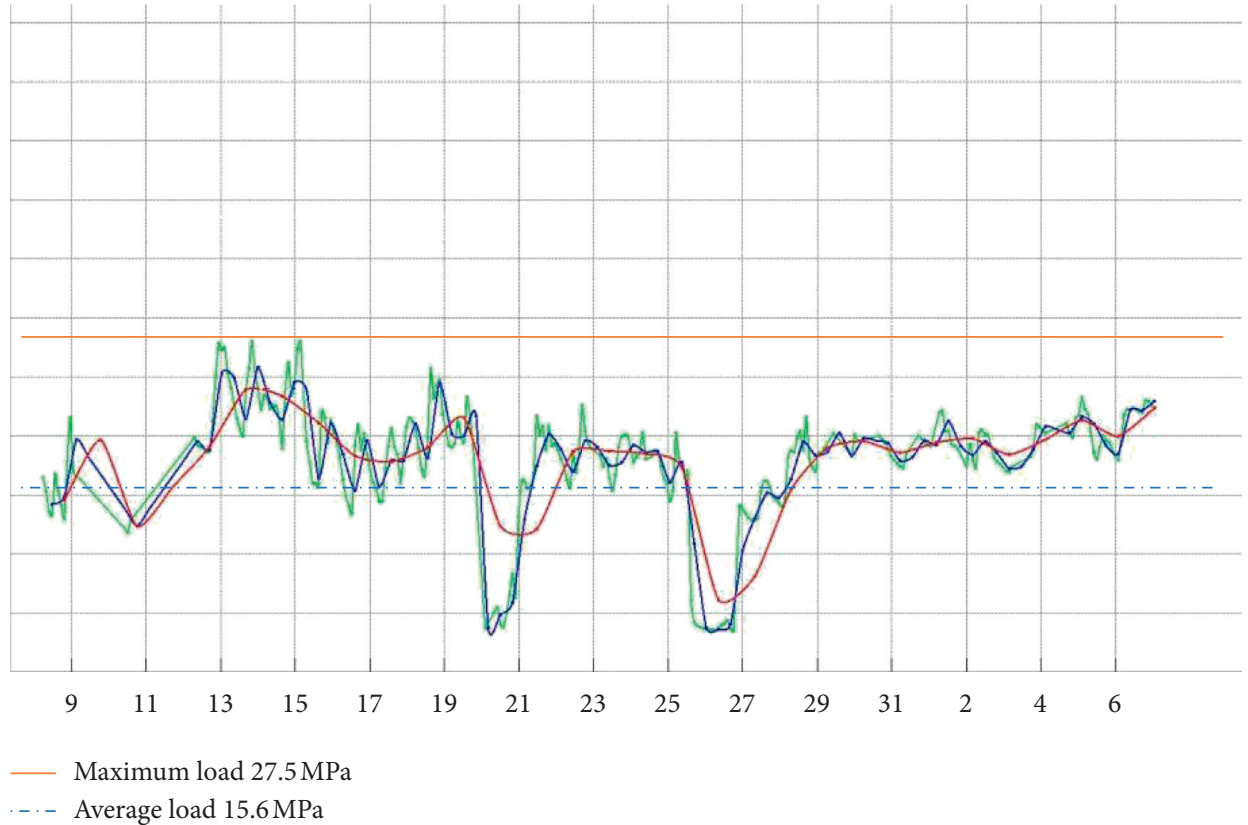

(c)

FIGURE 9: Working resistance monitoring curves of hydraulic support. (a) Working resistance monitoring curves of hydraulic support in the upper area. (b) Working resistance monitoring curves of hydraulic support in the middle area. (c) Working resistance monitoring curves of hydraulic support in the lower area.

TABLE 1: Working resistance of hydraulic support in the 3307 working face.

\begin{tabular}{lcc}
\hline Partition & The maximum pressure $(\mathrm{MPa})$ & The average pressure $(\mathrm{MPa})$ \\
\hline Upper area & 37.4 & 30.5 \\
Middle area & 35.2 & 29.2 \\
Lower area & 27.5 & 15.6 \\
\hline
\end{tabular}
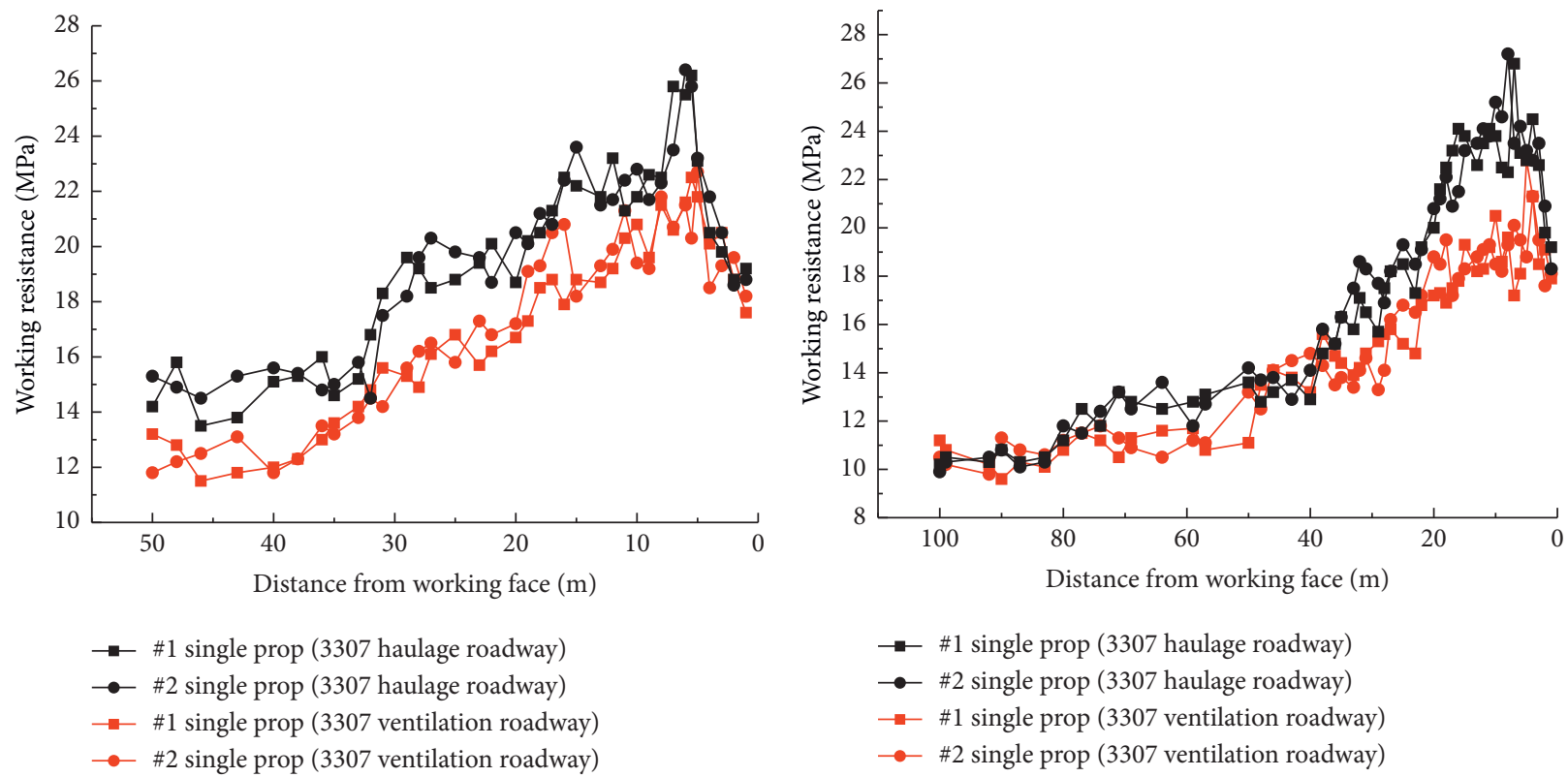

$\rightarrow$ \#1 single prop (3307 haulage roadway)

- \#2 single prop (3307 haulage roadway)

$\rightarrow$ \#1 single prop (3307 ventilation roadway)

- \#2 single prop (3307 ventilation roadway)

(a)

(b)

Figure 10: Continued. 


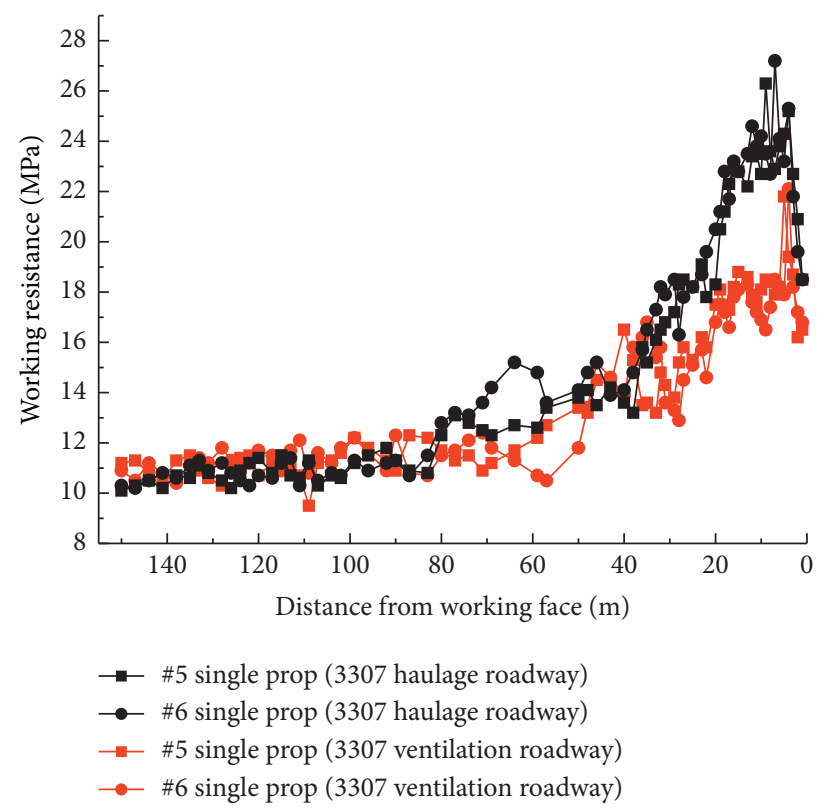

(c)

FIGURE 10: Working resistance of the single prop in front of the working face. (a) Monitoring curves of the single prop $50 \mathrm{~m}$ ahead of working face. (b) Monitoring curves of the single prop $100 \mathrm{~m}$ ahead of working face. (c) Monitoring curves of the single prop $150 \mathrm{~m}$ ahead of working face.

TABLE 2: The influence range and value of lead abutment pressure.

\begin{tabular}{|c|c|c|c|c|c|}
\hline \multirow{2}{*}{ Position } & \multicolumn{2}{|c|}{ Range } & \multicolumn{2}{|c|}{ Peak stress } & \multirow{2}{*}{ Average stress $(\mathrm{MPa})$} \\
\hline & Affected area $(\mathrm{m})$ & Violent zone $(\mathrm{m})$ & Ahead of the face $(\mathrm{m})$ & Value (MPa) & \\
\hline Haulage roadway & 80 & 30 & 7 & 27.2 & 16.7 \\
\hline Ventilation roadway & 50 & 20 & 5 & 22.7 & 15.3 \\
\hline
\end{tabular}

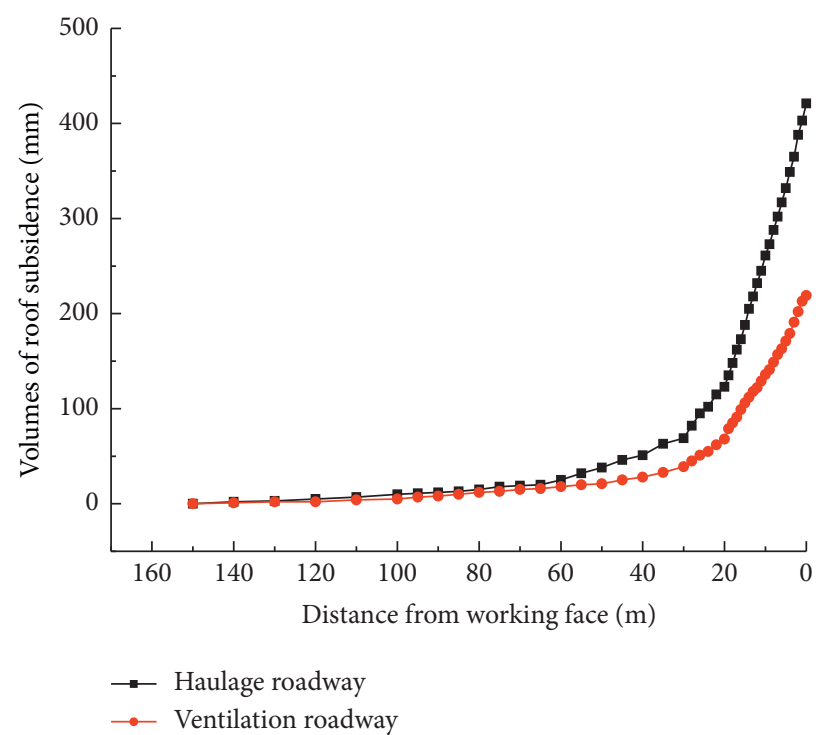

(a)

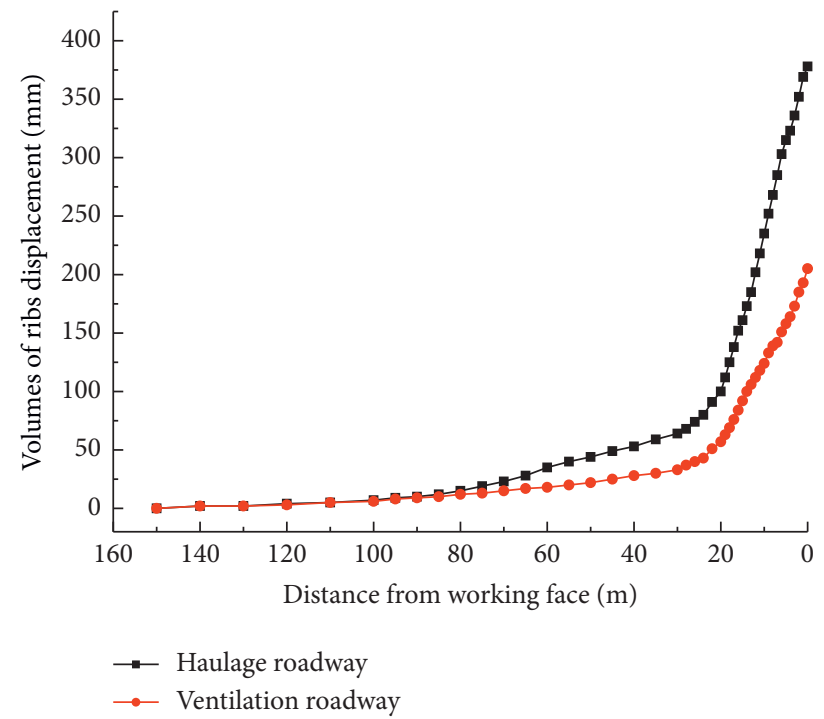

(b)

FIGURE 11: Continued. 


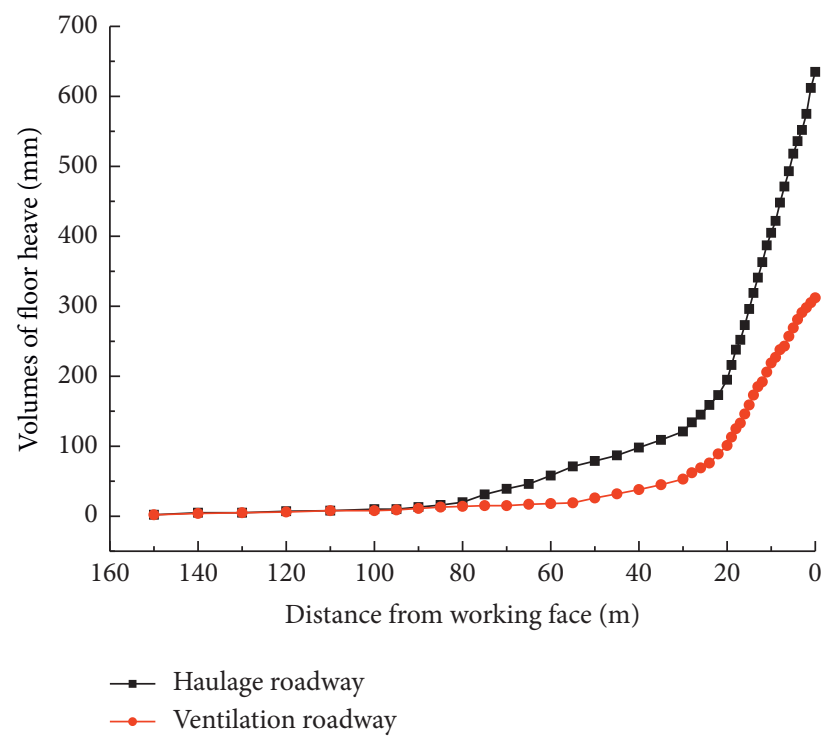

(c)

FIgURE 11: The on-site monitoring curves. (a) On-site monitoring curves of roof subsidence. (b) On-site monitoring curves of ribs displacement. (c) On-site monitoring curves of floor heave.

abutment pressure is reduced, the stress value is also reduced, and the effect of pressure relief is good. The results of monitoring data analysis are shown in Table 2.

In the 3307 ventilation roadway and haulage roadway, a monitoring point was arranged every $50 \mathrm{~m}$ to monitor the amount of roof subsidence, approaching of two ribs, and floor heave. For the convenience of analysis, this article only analyses the deformation of the roadway within $150 \mathrm{~m}$ from the open cut. The on-site monitoring curves are shown in Figure 11.

As shown in Figure 11, the deformation of the 3307 ventilation roadway is much smaller than that of the 3307 haulage roadway. Compared with the 3307 haulage roadway, the maximum value of the roof subsidence of the 3307 ventilation roadway is $219 \mathrm{~mm}$, which is a reduction of $47.9 \%$; the maximum value of the ribs displacement is $205 \mathrm{~mm}$, which is a reduction of $45.7 \%$; the maximum value of the floor heave is $312 \mathrm{~mm}$, which is a reduction of $50.7 \%$. It can be seen that after presplitting blasting of the roof strata of the roadway, the deformation of the roadway is significantly reduced, and the effect of controlling the roadway deformation is significant.

\section{Conclusions}

Based on the engineering background of the 3307 ventilation roadway of Xingcun Coal Mine, this paper studies the large deformation of the deep mine roadway through theoretical analysis, numerical simulation, and on-site monitoring. The main conclusions are as follows:

(1) Using Flac3d software, the two working conditions of presplitting blasting and non-presplitting blasting of the roadway roof strata were numerically simulated. The results showed that (a) After presplitting blasting the roadway roof strata, a pressure relief zone will be formed within $30 \mathrm{~m}$ of the blasting side of the working face and the surrounding rock stress reduced significantly.

(b) Because presplitting blasting cuts off the stress transmission path between the roof strata of the roadway and gob, it forces the stress concentration area to shift to the depth of the coal body. Without presplitting blasting, the stress concentration area of the surrounding rock of the roadway is about $8.2 \mathrm{~m}$ away from the roadside. After presplitting blasting, the stress concentration area of the surrounding rock of the roadway is about $12.8 \mathrm{~m}$ away from the roadside. The presplitting blasting the roof strata of the roadway has significantly improved the stress distribution of the surrounding rock.

(2) The working face was divided into three areas for monitoring on site. The 30 hydraulic supports on the side without presplitting blasting are the upper area, the 30 hydraulic supports on the presplitting blasting side are the lower area, and the rest are the middle area. The results show that compared with the middle area, the maximum working resistance of the hydraulic support in the lower area is reduced by $21.9 \%$ and the average value is reduced by $46.6 \%$; compared with the upper area, the maximum working resistance of the hydraulic support in the lower area is reduced by $26.5 \%$; and the average value is reduced by $48.9 \%$, and the pressure relief effect is significant. 
(3) On-site monitoring of the lead abutment pressure and the deformation of the 3307 ventilation roadway and haulage roadway. The results show that

(a) Compared with the 3307 haulage roadway, the 3307 ventilation roadway's lead abutment pressure influence zone is $50 \mathrm{~m}$, a decrease of $37.5 \%$, and the violent zone is $20 \mathrm{~m}$, a reduction of $33.3 \%$. The maximum value is $22.7 \mathrm{MPa}$, a decrease of $16.5 \%$, and the average value is 15.3 $\mathrm{MPa}$, reduced by $8.4 \%$.

(b) Compared with the 3307 haulage roadway, the maximum value of roof subsidence of the 3307 ventilation roadway is $219 \mathrm{~mm}$, which is reduced by $47.9 \%$, the maximum value of the ribs displacement is $205 \mathrm{~mm}$, which is reduced by $45.7 \%$, and the maximum value of floor heave is $312 \mathrm{~mm}$, which is reduced by $50.8 \%$.

(4) Through numerical simulation and field tests, it can be known that presplitting blasting the roof strata can effectively improve the stress distribution of the roadway and has a significant effect on controlling the large deformation of the roadway.

\section{Data Availability}

All the data used to support the findings of this study are available from Chaowen $\mathrm{Hu}$ upon request.

\section{Conflicts of Interest}

The authors declare that they have no conflicts of interest.

\section{Authors' Contributions}

Chaowen $\mathrm{Hu}$ and Xiaojie Yang were responsible for conceptualization of the study; Chaowen $\mathrm{Hu}$ was responsible for methodology; Chaowen $\mathrm{Hu}$ and Ruifeng Huang were responsible for software; Chaowen $\mathrm{Hu}$ and Xingen Ma were involved in data curation.

\section{Acknowledgments}

This work was supported by the Inner Mongolia Natural Science Foundation (grant no. 2020BS05004), the Innovation Fund Project of Inner Mongolia University of Science and Technology (grant no.2019QDL-B34), the State Key Laboratory for Geomechanics and Deep Underground Engineering (SKLGDUEK2020), and China University of Mining and Technology (Beijing), which are gratefully acknowledged.

\section{References}

[1] W. Huang, K. Zhang, X. Tang, Z. Zhao, and H. Wan, "Coking coals potential resources prediction in deep coal beds in Northern China," Energy Exploration \& Exploitation, vol. 28, no. 4, pp. 313-325, 2010.
[2] M. Song, J. Wang, and J. Zhao, "Coal endowment, resource curse, and high coal-consuming industries location: analysis based on large-scale data," Resources, Conservation and Recycling, vol. 129, pp. 333-344, 2018.

[3] X. Chen, L. Li, L. Wang, and L. Qi, “The current situation and prevention and control countermeasures for typical dynamic disasters in kilometer-deep mines in China," Safety Science, vol. 115, pp. 229-236, 2019.

[4] B. Li, N. Zhou, W. Qi, A. Li, and Z. Cui, "Surface subsidence control during deep backfill coal mining: a case study," Advances in Civil Engineering, vol. 2020, Article ID 6876453, 12 pages, 2020.

[5] H. Xie, Y. Ju, S. Ren, F. Gao, J. Liu, and Y. Zhu, “Theoretical and technological exploration of deep in situ fluidized coal mining," Frontiers in Energy, vol. 13, no. 4, pp. 603-611, 2019.

[6] P. G. Andrews, R. J. Butcher, and J. Ekkerd, "The geotechnical evolution of deep-level mechanized destress mining at South Deep mine," Journal of the Southern African Institute of Mining and Metallurgy, vol. 120, no. 1, pp. 33-40, 2020.

[7] G. G. Sakantsev, M. G. Sakantsev, V. I. Cheskidov, and V. K. Norri, "Improvement of deep-level mining systems based on optimization of accessing and open pit mine parameters," Journal of Mining Science, vol. 50, no. 4, pp. 714-718, 2014.

[8] Z. Guo, Q. Wang, Z. Li et al., "Surrounding rock control of an innovative gob-side entry retaining with energy-absorbing supporting in deep mining," International Journal of LowCarbon Technologies, vol. 14, no. 1, pp. 23-35, 2019.

[9] X. Y. Yu and X. W. Mao, "A preliminary discrimination model of a deep mining landslide and its application in the Guanwen coal mine," Bulletin of Engineering Geology and the Environment, vol. 79, no. 1, pp. 485-493, 2020.

[10] Anonymous, "The social need for deep coal mining in Europe should be re-evaluated against unreasonable levels of subsidies: UK DTI statements on miners' health 1999/2000," Energy Exploration \& Exploitation, vol. 18, no. 1, pp. 113-120, 2000.

[11] M. B. D. Aguado and C. Gonzalez, "Influence of the stress state in a coal bump-prone deep coalbed: a case study," International Journal of Rock Mechanics and Mining Sciences, vol. 46, no. 2, pp. 333-345, 2009.

[12] C. Hu, W. Liu, and Y. Wang, "Study on the influence of the location of dirt band on top coal caving property in extrathick coal seam," Geotechnical and Geological Engineering, vol. 38, no. 6, p. 6221, 2020.

[13] G.-L. Guo, W.-K. Feng, J.-F. Zha, Y.-X. Liu, and Q. Wang, "Subsidence control and farmland conservation by solid backfilling mining technology," Transactions of Nonferrous Metals Society of China, vol. 21, no. 3, pp. s665-s669, 2011.

[14] D. Wang, Y. Jiang, X. Sun, H. Luan, and H. Zhang, "Nonlinear large deformation mechanism and stability control of deep soft rock roadway: a case study in China," Sustainability, vol. 11, no. 22, pp. 6243-22, 2019.

[15] X. Yang, C. Hu, J. Liang, Y. Zhou, G. Ni, and R. Huang, “A case study on the control of large deformations in a roadway located in the du'erping coal mine in China," Advances in Materials Science and Engineering, vol. 2019, Article ID 9628142, 13 pages, 2019.

[16] F. Feng, X. B. Li, J. Rostami, and D. Y. Li, "Modeling hard rock failure induced by structural planes around deep circular tunnels," Engineering Fracture Mechanics, vol. 205, pp. 152174, 2019.

[17] J. Xu, R. Zhou, D. Song, N. Li, K. Zhang, and D. Xi, “Deformation and damage dynamic characteristics of coal-rock 
materials in deep coal mines," International Journal of Damage Mechanics, vol. 28, no. 1, pp. 58-78, 2019.

[18] E. B. Aygar, "Evaluation of new Austrian tunnelling method applied to Bolu tunnel's weak rocks," Journal of Rock Mechanics and Geotechnical Engineering, vol. 12, no. 3, pp. 541-556, 2020.

[19] K. Yu, F. Ren, R. Puscasu, P. Lin, and Q. Meng, "Optimization of combined support in soft-rock roadway," Tunnelling and Underground Space Technology, vol. 103, Article ID 103502, 2020.

[20] S. Q. Li, X. F. Sun, Z. Y. Ye, and Y. L. Tan, "Analysis of bearing structures around deep soft rock roadway," Disaster Advances, vol. 6, no. 6, pp. 250-255, 2013.

[21] B. Shen, "Coal mine roadway stability in soft rock: a case study," Rock Mechanics and Rock Engineering, vol. 47, no. 6, pp. 2225-2238, 2014.

[22] C. Zhao, Y. Li, G. Liu, and X. Meng, "Mechanism analysis and control technology of surrounding rock failure in deep soft rock roadway," Engineering Failure Analysis, vol. 115, Article ID 104611, 2020.

[23] C. Wang, L. Liu, D. Elmo et al., "Improved energy balance theory applied to roadway support design in deep mining," Journal of Geophysics and Engineering, vol. 15, no. 4, pp. 1588-1601, 2018.

[24] C. Gao, D. Huang, X. Chang, and H. Xi, "Risk analysis and extension assessment for the stability of surrounding rock in deep coal roadway," International Journal of Environmental Research and Public Health, vol. 16, no. 23, p. 4752, 2019.

[25] L. Jiang, P. Wang, P. Zheng, H. Luan, and C. Zhang, "Influence of different advancing directions on mining effect caused by a fault," Advances in Civil Engineering, vol. 2019, Article ID 7306850, 10 pages, 2019.

[26] B. Yuan, M. Sun, L. Xiong, Q. Luo, S. P. Pradhan, and H. Li, "Investigation of 3D deformation of transparent soil around a laterally loaded pile based on a hydraulic gradient model test," Journal of Building Engineering, vol. 28, no. 3, Article ID 101024, 2020.

[27] B. X. Yuan, M. Sun, Y. X. Wang, L. H. Zhai, and Q. Z. Luo, "Full 3D displacement measuring system for 3D displacement field of soil around a laterally loaded pile in transparent soil," International Journal of Geomechanics, vol. 19, no. 5, 2019.

[28] X. Yang, C. Hu, M. He et al., "Study on presplitting blasting the roof strata of adjacent roadway to control roadway deformation," Shock and Vibration, vol. 2019, Article ID 3174898, 16 pages, 2019.

[29] B. Chen and C. Liu, "Analysis and application on controlling thick hard roof caving with deep-hole position presplitting blasting," Advances in Civil Engineering, vol. 2018, Article ID 9763137, 15 pages, 2018.

[30] N. Zhang, C. Liu, and B. Chen, "A case study of presplitting blasting parameters of hard and massive roof based on the interaction between support and overlying strata," Energies, vol. 11, no. 6, p. 1363, 2018.

[31] L. Ma, K. Li, S. Xiao, X. Ding, and S. Chinyanta, "Research on effects of blast casting vibration and vibration absorption of presplitting blasting in open cast mine," Shock and Vibration, vol. 2016, Article ID 4091732, 9 pages, 2016.

[32] X. L. Li, Q. W. Hu, X. B. Ma, K. G. Li, and J. Q. Xiao, "Experimental research on presplitting blasting of the final highwall of an opencast coal mine," Journal of the Balkan Tribological Association, vol. 22, no. 3, pp. 2857-2869, 2016.

[33] K. Liu, X. Li, H. Hao et al., "Study on the raising technique using one blast based on the combination of long-hole presplitting and vertical crater retreat multiple-deck shots,"
International Journal of Rock Mechanics and Mining Sciences, vol. 113, pp. 41-58, 2019.

[34] B. Yuan, L. Xiong, L. Zhai et al., "Transparent synthetic soil and its application in modeling of soil-structure interaction using optical system," Frontiers in Earth Science, vol. 7, 2019.

[35] F. Feng, S. Chen, D. Li, S. Hu, W. Huang, and B. Li, "Analysis of fractures of a hard rock specimen via unloading of central hole with different sectional shapes," Energy Science \& Engineering, vol. 7, no. 6, p. 2265, 2019.

[36] F. Feng, X. B. Li, J. Rostami, D. X. Peng, D. Y. Li, and K. Du, "Numerical investigation of hard rock strength and fracturing under polyaxial compression based on Mogi-Coulomb failure criterion," International Journal of Geomechanics, vol. 19, no. 4, Article ID 04019005, 2019. 